\title{
SYNTHESIS AND PREPARATION OF HYDROPHOBIC CNTS-COATED MELAMINE FORMALDEHYDE FOAM BY GREEN AND SIMPLE METHOD FOR EFFICIENT OIL/WATER SEPARATION
}

\author{
The-Anh Phan ${ }^{1}{ }^{凶}$, Kim-Hoang Dang ${ }^{1}$, Lam Nguyen-Dinh ${ }^{1}$
}

https://doi.org/10.23939/chcht14.04.531

\begin{abstract}
Herein, we present a green, simple and costeffective method to change hydrophilic melamine formaldehyde (MF) foam to hydrophobic carbon nanotubes (CNTs) coated MF foam through an immersion process. The MF foam was produced from the MF resin which was synthesized in a laboratory by a condensation reaction between melamine and formaldehyde under alkaline condition with a molar ratio of melamine to formaldehyde of 1:3. The MF foam has an open-cell structure with the average pore diameter of $350 \mu \mathrm{m}$, density of $25 \mathrm{~kg} \cdot \mathrm{m}^{-3}$ and porosity of $98 \%$. The asprepared CNTs-coated MF foam exhibits high sorption capacity $(23-66 \mathrm{~g} / \mathrm{g})$ for oils and organic solvents, good recyclability and high selectivity.
\end{abstract}

Keywords: carbon nanotube, melamine foam, melamine formaldehyde, oil spills, sorbent material.

\section{Introduction}

Oil spill accidents from the exploration, production, transportation, storage and utilization activities usually cause severely ecological and environmental damage. The rate of such accidents increases with the development of the industry. Therefore, materials that can effectively eliminate spilled oils or organic contaminants from water are in highly demand. In practice, oil spills are cleaned up by using different methods such as oil dispersant [1], oil gelling agent, mechanical extraction [2], biological method [3] and sorbent materials [4]. Among these methods, the use of sorbent materials has been shown as the most effective and promising option for removing oil from water surface $[4,5]$. Traditionally, there are three kinds of oil sorbent materials including inorganic, synthetic organic and natural organic materials.

\footnotetext{
${ }^{1}$ The University of Danang, University of Science and Technology,

54 Nguyen Luong Bang, Danang, Viet Nam

ptanh@dut.udn.vn

(c) Phan T-A., Dang K-H., Nguyen-Dinh L., 2020
}

The inorganic sorbents such as clay, bentonite, zeolites and activated carbon are cheap and available. However, they have low oil sorption capacity and poor recyclability. The natural organic sorbents such as feather, cotton, wool, rice husk $[6,7]$ absorb not only oils but also water due to their hydrophilic nature and have low oil sorption capacity. Although the synthetic organic sorbents such as polypropylene fiber, polyurethane foam [8], poly(alkyl acrylate) foam [9], rubber [10] are most commonly used for oil spill cleanup due to their hydrophobic and oleophilic characteristics, but they have low oil sorption capacity. Hence, it would be a challenge to find a robust material that meets requirements such as high sorption capacity, high selectivity, simple processing, high recyclability and environmental friendliness.

Recently, carbon-based materials have attracted tremendous attention as the best candidate for oil spill cleanup [11, 12]. Different forms of carbon-based sorbents such as superhydrophobic and superoleophilic carbon nanotubes [13] or grapheme [14] sponges, CNT and graphene aerogel $[15,16]$ and carbon fibers have been developed and applied to remove oils from water. However, the practical application of these materials is still limited because of their complex preparation processes, high-cost and the destruction of porous structures during the post-treatment process[15, 17].

The polymer-based 3D porous materials have a high volume to weight ratio, so they can store a large amount of absorbed liquid inside the structure. However, these materials present a poor oil sorption capacity due to their hydrophilicity. The deposition of carbon-based materials on polymer-based 3D porous materials to switch the wettability of the porous material from superhydrophilic to superhydrophobic has also been studied [16, 18, 19]. These study results show that obtained products have high oil sorption capacity. However, most of the deposition pathway exhibit limitations such as: they produce a large volume of by-products, consume a large amount of organic solvents, as well as expensive modifying agents during the preparation processes. 
In this study, we fabricated a hydrophobic CNTscoated 3D MF foam for the selective sorption of oils from water using a green and simple method. The MF foam is produced in the laboratory from the synthesized MF resin by the microwave irradiation, followed by coating a CNTs layer. The coating is realized by immersing the MF foam into CNTs aqueous suspension containing the egg white. The as-prepared CNTs-coated MF foam presents a broad sorption of oils and common organic solvents with high selective, high sorption capacity and good recyclability. Taking into account a facile fabrication, as well as a high performance of obtained product, we believe that such CNTs-coated MF foam will have great potential for the field of oil spill cleanup.

\section{Experimental}

\subsection{Materials}

Melamine ( $\geq 99 \%$, Merck), formaldehyde solution ( $\sim 37 \%$, Merck), sodium hydroxide ( $\geq 99 \%$, Merck), dodecybenzene sulfonic acid (DBSA, $\geq 95 \%$ ), hexane (anhydrous, 95\%) and formic acid (95-97\%) were purchased from Sigma Aldrich. CNTs were synthesized in the laboratory by the chemical vapor deposition (CVD). The deionized water was used to disperse CNTs and for all others purposes. All chemicals were used without further purification.

\subsection{Preparation of MF Resin}

Melamine and formaldehyde ( $\sim 37 \mathrm{wt} \%$ in water) with the molar ratio of 1:3 were added into a three-necked round-bottom flask equipped with a magnetic stirrer, a condenser and a thermometer. Before methyolation reaction, $\mathrm{pH}$ of the reaction mixture was adjusted to 8.5 by adding a sufficient amount of $1 \mathrm{M} \mathrm{NaOH}$ solution followed by heating at $358 \mathrm{~K}$ for $2-3 \mathrm{~h}$ to obtain a clear and viscous liquid. In order to characterize the properties of the synthesized MF resin, sodium hydroxide catalyst was removed from the product by dropping the reaction mixture into a beaker with an excess of water under stirring. The white solid was then collected and dried at $333 \mathrm{~K}$ to a constant weight. In order to produce MF foam, the obtained resin solution was cooled to room temperature and used as a precursor.

\subsection{Preparation of MF Foam}

The MF foam was prepared by the microwave irradiation method. First, 4 wt $\%$ of DBSA as a stabilizer, $8 \mathrm{wt} \%$ of hexane as a foaming agent and $2 \mathrm{wt} \%$ of formic acid as cured agent were added into the synthesized MF resin solution and agitated by a high speed stirrer. Then, the obtained homogenous mixture was irradiated under microwave at $700 \mathrm{~W}$ for $2 \mathrm{~min}$. Finally, the MF foam was put into an oven at $393 \mathrm{~K}$ for $24 \mathrm{~h}$ to remove residual formaldehyde, formic acid, water and for further crosslinking to transfer ether bridges to methylene bridges.

\subsection{Preparation of CNTs-Coated MF Foam}

Hydrophobic CNTs-coated MF foam was prepared by an immersion method. First, CNTs suspension was prepared by adding $0.2 \mathrm{~g}$ of CNTs into $100 \mathrm{ml}$ of deionized water containing $10 \mathrm{~g}$ of egg white followed by a magnetic agitation for $10 \mathrm{~min}$. The suspension was sonicated for $4 \mathrm{~h}$ by using a probe ultrasonic processor (Bandelin Sonopuls HD 2200, 10\% amplitude modulation, $950 \mathrm{~W}$, provided in pulse mode of $1 \mathrm{~s}$ on and $5 \mathrm{~s}$ off). During the sonication, the suspension was placed in an ice bath in order to prevent the aggregation and denature of egg white. Finally, the as-prepared MF foam $(3 \times 2.5 \times 2.5 \mathrm{~cm}$ in size $)$ was immersed into the CNTs suspension and sonicated for $30 \mathrm{~min}$ to ensure a uniform penetration in the entire volume of the foam followed by oven drying at $393 \mathrm{~K}$ for $24 \mathrm{~h}$.

\subsection{Characterization}

Thermo Nicolet iS10-Thermo Scientific instrument was used to record FTIR spectra. Samples were mixed with $\mathrm{KBr}$ and further compressed into pellets for measurements. The infrared spectra were obtained for 64 scans and resolution of $4 \mathrm{~cm}^{-1}$ in the region between 4000 and $400 \mathrm{~cm}^{-1}$. TGA was performed using a TA Instrument apparatus (STA 6000). The sample was heated to $973 \mathrm{~K}$ with a rate of $10 \mathrm{~K} \cdot \mathrm{min}^{-1}$ in $100 \mathrm{ml}$ of nitrogen. All the contact angle measurements were performed at room temperature using a sessile drop method with a DIGIDROP contact angle meter from GBX Instruments. $5 \mu \mathrm{l}$ of distilled water was gently deposited on the surface of a sorbent by using a micro-syringe. The average contact angle values were determined by measuring the substrate at five different positions. Obtained images of the contact angles were analyzed using Windrop software.

\subsection{Oil Sorption Tests}

The oil sorption capacity of the CNTs-coated MF foam was determined based on ASTM F716 and F726. All tests were repeated by three times at ambient temperature. The oil sorption capacity of the CNTs-coated MF foam $(C$, $\mathrm{g} / \mathrm{g}$ ) was calculated using the following equation:

$$
C=\frac{m_{t}-m_{0}}{m_{0}}
$$

where $m_{0}$ is the initial dry weight of the CNTs-coated MF foam, $\mathrm{g} ; m_{t}$ is the weight of the CNTs-coated MF foam after sorption, $\mathrm{g}$. 


\section{Results and Discussion}

\subsection{Structure and Thermal Properties of MF Resin}

Polymerization of melamine and formaldehyde occurs in two steps [20,21]. The first step is the addition reaction of formaldehyde to melamine to form methylol compounds. This methylolation step is carried out in neutral or weakly alkaline condition to avoid the gelationof the formed methylol compounds which are unstable in acidic environment. The trimethylolmelamines are formed in this case due to the molar ratio of melamine and formaldehyde of 1:3. The second step is the condensation reaction between the methylol compounds resulting in the formation of a large number of different oligomers containing methylene ether and methylene bridges $[22,23]$. It is important to note that the crosslinking reaction between methylol compounds to form an insoluble and infusible product does not occur in this step. The cross-linking reaction takes place favorably at the temperatures above $433 \mathrm{~K}$. The FTIR spectra of pristine melamine, the synthesized MF resin and cured MF resin are shown in Fig. 1. In the pristine melamine spectrum, two peaks at 3467 and $3415 \mathrm{~cm}^{-1}$ correspond to the $\mathrm{N}-\mathrm{H}$ stretching vibrations and three peaks at 3332, 3187 and $1626 \mathrm{~cm}^{-1}$ - to the $\mathrm{N}-\mathrm{H}$ bending vibrations of primary amine[20, 24]. In the spectrum of the MF resin, the characteristic peaks of primary amine of melamine disappeared and were replaced by the appearance of the broad peak at $3340 \mathrm{~cm}^{-1}$ which is assigned to the $\mathrm{N}-\mathrm{H}$ stretching vibration of secondary amine and the $\mathrm{O}-\mathrm{H}$ stretching vibration of methylol groups. The peaks at around $3000 \mathrm{~cm}^{-1}$ and in $1360-1450 \mathrm{~cm}^{-1}$ region are attributed to the $\mathrm{C}-\mathrm{H}$ stretching and bending vibrations of methylol groups, respectively. These results proved the formation of methylol groups from melamine and formaldehyde. The peaks at 1550 and $809 \mathrm{~cm}^{-1}$ are assigned to the $-\mathrm{C}=\mathrm{N}$ stretching vibration and bending vibration of triazine ring, respectively [20]. The peaks at 1160 and $1060 \mathrm{~cm}^{-1}$ correspond to the stretching vibration of $\mathrm{C}-\mathrm{O}$ and $\mathrm{C}-\mathrm{O}-\mathrm{C}$ groups. These peaks are not observed in the spectrum of pristine melamine. The FTIR spectrum of the cured MF resin is similar to that of the MF resin. However, the peak intensity of methylol and $\mathrm{C}-\mathrm{O}-\mathrm{C}$ groups in the spectrum of cured MF resin decreases. The decrease of peak intensity at $3340 \mathrm{~cm}^{-1}$ could be explained by the condensation reaction of the methylol groups. The releasing of formaldehyde from the ether bridge during the curing could lead to the decreasing of peak intensity at 1360,1160 and $1060 \mathrm{~cm}^{-1}$.

The thermal properties of the synthesized MF resin were studied by means of thermogravimetric analysis and shown in Fig. 2. It can be seen that the thermal decomposition of MF resin exhibits five steps of weight loss. The first step occurs at the temperatures from 303 to $423 \mathrm{~K}$ with a weight loss of $9 \%$ due to the evaporation of physical water and chemical water which is formed from the condensation reaction of methylol groups. The second step occurring within $423-473 \mathrm{~K}$ with a weight loss of $6 \%$ may be due to the water elimination from the selfcondensation of methylol groups and from the condensation reaction between methylol groups and melamine. The third step of weight loss corresponds to the formaldehyde elimination from the ether bridge, which takes place between 473 and $623 \mathrm{~K}$ [20]. The weight loss in this step is $14.3 \%$. The main weight loss of $29 \%$ at the fourth step observed in the temperature range of $623-683 \mathrm{~K}$ is attributed to the breakdown of methylene bridges [25]. The last weight loss of $22.8 \%$ occurring in the temperature range of $683-973 \mathrm{~K}$ is assigned to the thermal decomposition of triazine ring [26].

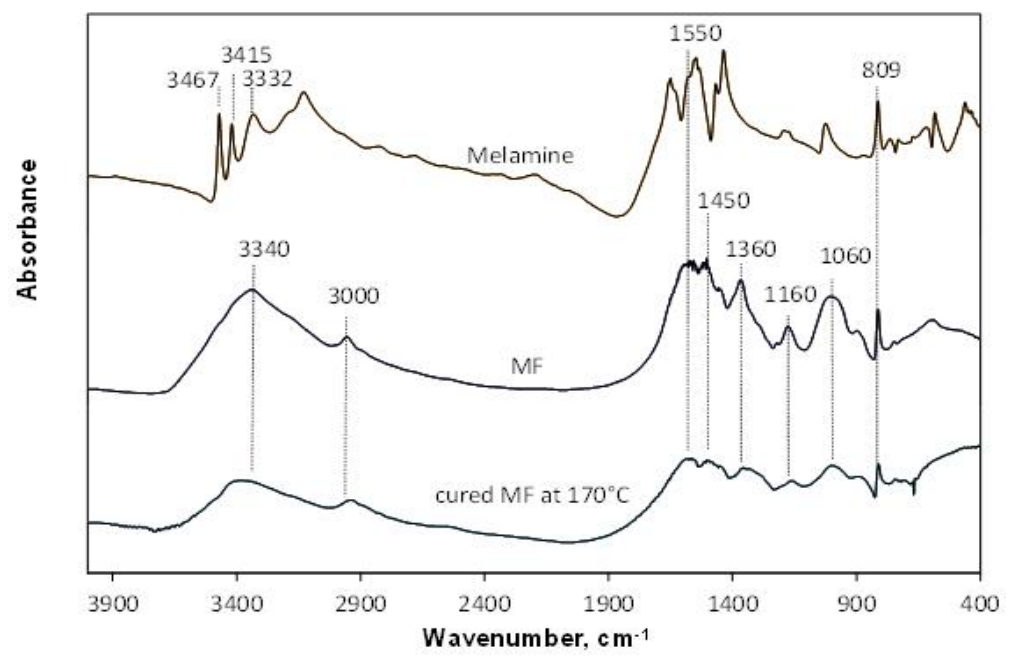

Fig. 1. FTIR spectra of pristine melamine, the MF resin and cured MF resin at $443 \mathrm{~K}$ 


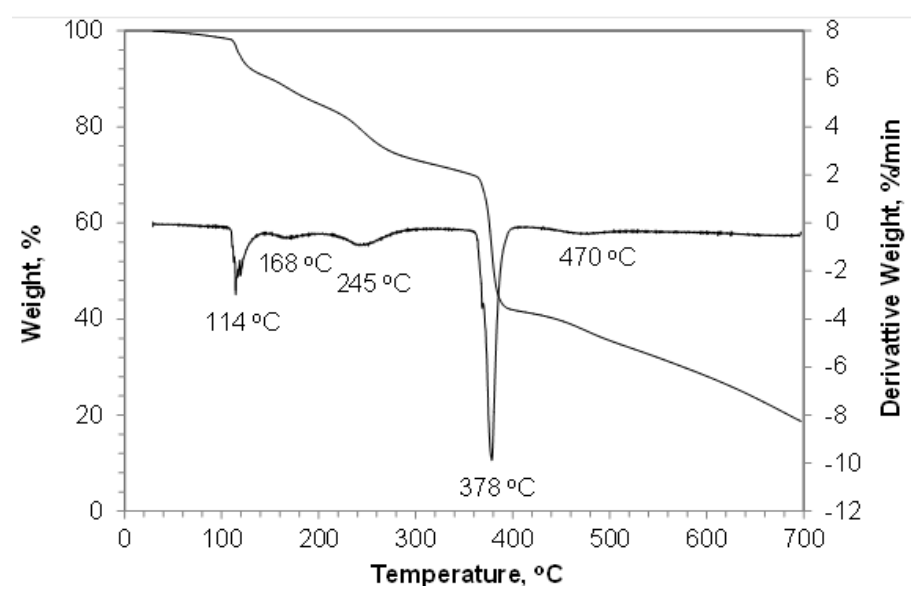

Fig. 2. TGA thermogram of the synthetized MF resin

\subsection{Characterization of Uncoated and CNTs-Coated MF Foams}

Fig. 3 presents TG curves of CNTs, MF foam and CNTs-coated MF foam collected under oxygen. The TG curve of CNTs shows a slight weight increase of $1.2 \%$ in the 303-673 K temperature range due to the oxidation and a strong weight loss at $873 \mathrm{~K}$ caused by the thermal decomposition of CNTs in oxygen. The residual content at the end of thermal degradation is around $11.7 \%$, that is attributed to a metal catalyst [27]. The TG curve of uncoated MF foam shows three steps of weight loss. The first step of weight loss $(5.2 \%)$ in the $303-423 \mathrm{~K}$ range is due to the evaporation of absorbed water. The second step occurring between 423 and $673 \mathrm{~K}$ can be attributed to the breakdown of methylene or ether bridges [25]. The third weight loss at the temperatures higher than $673 \mathrm{~K}$ is ascribed to the thermal degradation of the triazine ring [28]. As shown on the TG curve of the CNTs-coated MF foam, the presence of CNTs reduced the absorbed water content $(3.2 \%)$ and shifted the decomposition temperature to a higher temperature (about $15 \mathrm{~K}$ ) at temperature range above $873 \mathrm{~K}$.

The apparent density of the created MF foam is $25 \mathrm{~kg} \cdot \mathrm{m}^{-3}$, which is determined from a dried weight and volume of foam. The MF foam porosity is estimated to be $98 \%$ based on calculations using the apparent density of MF foam and a bulk density of $1500 \mathrm{~kg} \cdot \mathrm{m}^{-3}$ [29] for the MF resin. The high porosity is in accordance with SEM observations in Fig. 4a. It can be seen that the MF foam created from the synthesized MF resin by the microwave irradiation has an open-cell structure. The estimated average pore size and skeleton diameter, determined by Image $J$ software from SEM images, are about 350 and $30 \pm 3 \mu \mathrm{m}$, respectively. These results indicated that the created MF foam could be used as a good sorbent. As can be seen in Fig. $4 \mathrm{~b}$, there are many small pores with the diameter ranging from 1 to $2 \mu \mathrm{m}$ on the foam skeleton. This may be the reason for the low apparent density of created MF foam.

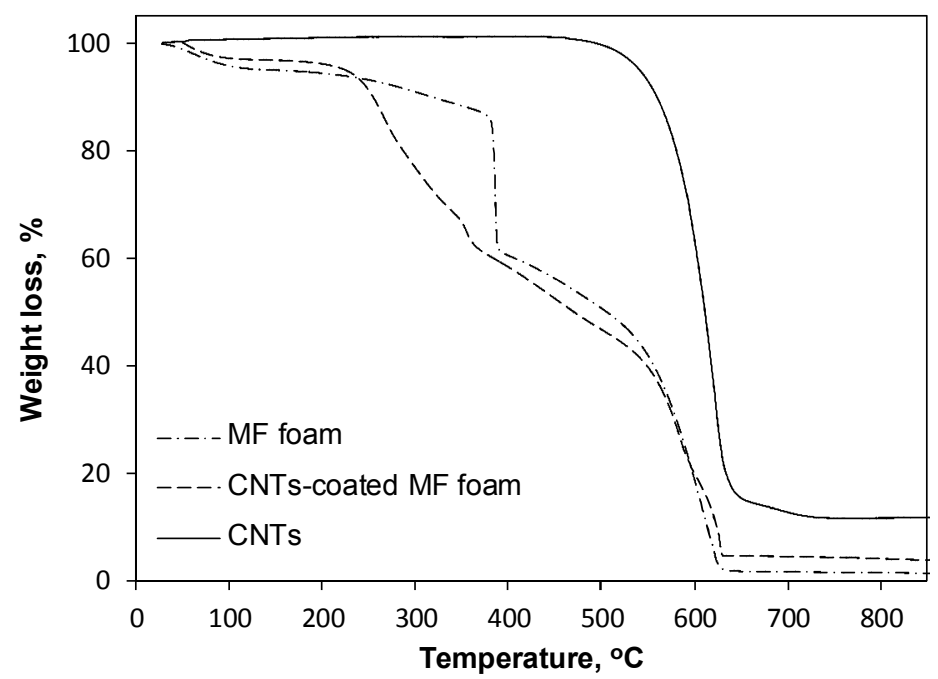

Fig. 3. TGA thermograms of CNTs, MF foam and CNTs-coated MF foam 

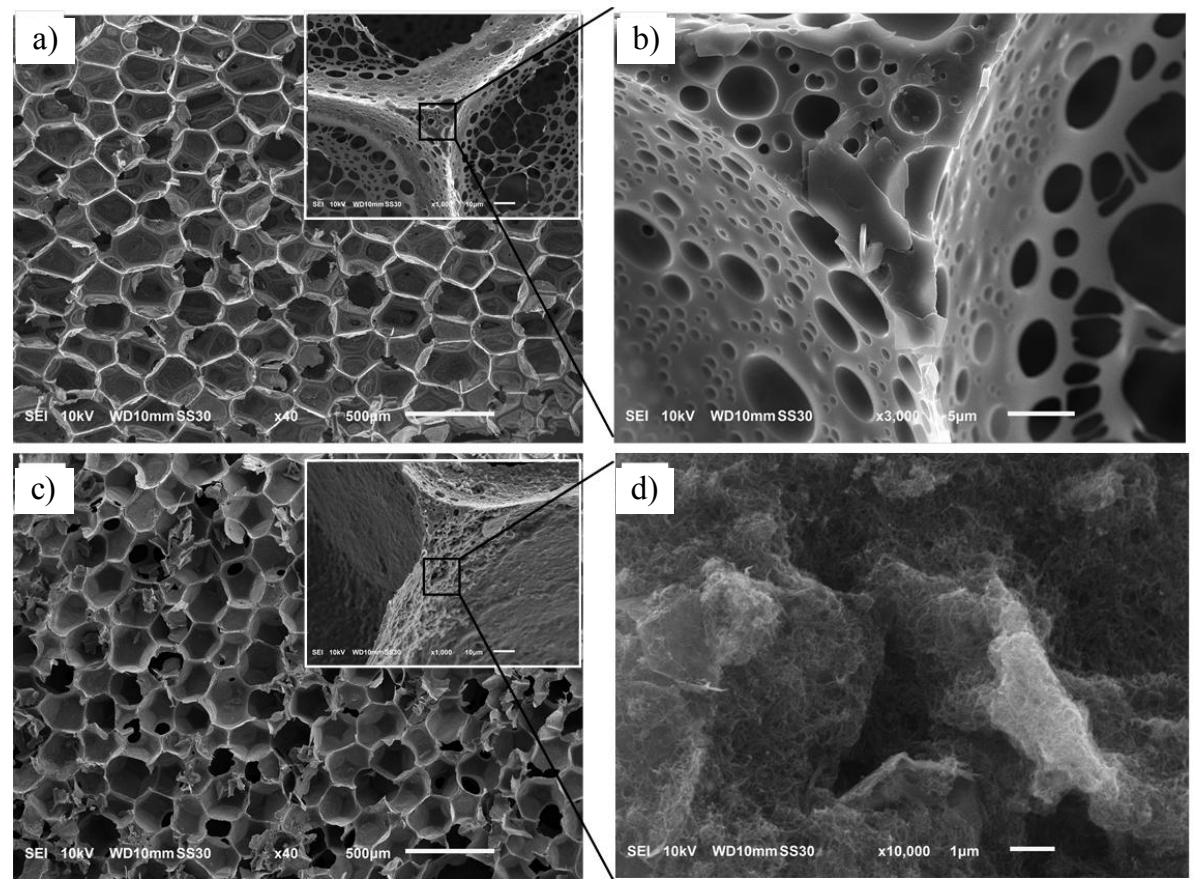

Fig. 4. SEM images at different magnifications: uncoated(a, b) and CNTs-coated (c, d) MF foam
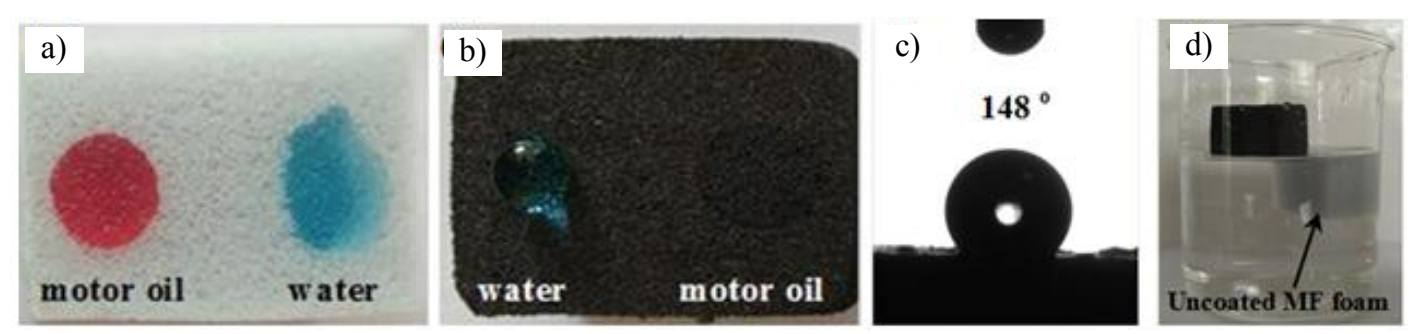

Fig. 5. Digital photos of water and motor oil droplets on the surface of uncoated MF foam (a)

and CNTs-coated MF foam (b), water contact angle (c) and photo of CNTs-coated MF foam float on the water surface (d)

Due to the hydrophilic nature of the MF foam, the CNTs aqueous suspension can easily penetrate into its entire porous structure. When water is vaporized, the CNTs will be deposited onto the skeleton of the foam by the coagulation of egg white and the strong van der Waals interactions between the MF foam and CNTs. From Fig. $4 \mathrm{c}$ (inset), it is clearly seen that the decoration of CNTs on the MF foam did not show any effect on its pristine porous structure but a much rougher skeleton surface of the CNT-coated MF foam was observed. The increase in surface roughness and the change of surface wetting nature can lead to the decrease of surface energy and the increase in oil sorption capacity of the CNTs-coated MF foam. Fig. 4d shows the agglomeration of CNTs nanoparticles on the foam skeleton.

The surface wetting behaviors of foams are evaluated by contact angle measurements. Figs. $5 \mathrm{a}$ and $5 \mathrm{~b}$ show digital photos of oil and water droplets placed on the surface of uncoated and CNTs-coated MF foam, respectively. It is easy to observe that while the uncoated MF foam absorbs not only oil but also water, the CNTscoated MF foam absorbs only oil. Water droplet dyed with methlene blue retains nearly spherical on the surface of CNTs-coated MF foam. The hydrophobic characterisics of CNTs-coated MF foam are confirmed by the water contact angle value of $148 \pm 1^{\circ}$ (Fig. 5c) and the floating of CNTs-coated MF foam on the water surface (Fig. 5d).

\subsection{Sorption Capacity and Recyclability of CNTs-Coated MF Foam}

The mass-based sorption capacity of CNTs-coated MF foam for common oily pollutants in industry or daily life such as benzene, chloroform, motor oil, crude oil and used soybean oil is shown in Fig. 6a. The results indicated that the CNTs-coated MF foam exhibits the high sorption 
capacity ranging from 23 to 66 times their own weight depending on the viscosity and density of the absorbed liquids. These results are comparable to reported results for carbon-based porous materials such as nitrogen-rich carbon aerogel (5-16 times) [15], CNT/PDMS coated PU sponge (15-25 times) [30] and macroporous carbon nanotubes (49-56 times) [31]. From the mass-based sorption capacity, the volume-based motor oil sorption capacity of the CNTs-coated MF foam is calculated about $92 \%$. This indicates that the entire volume of foam is used for oil storage and the CNTs-coated MF foam is an ideal sorbent for the removal of oily pollutants from water. From digital photos shown in Fig. 6b it can be seen that both the motor oil layer on methylene blue-dyed water and the motor oil-dyed chloroform layer at the bottom of water are quickly absorbed by the CNTs-coated MF foam. The air bubbles are released from the foam block when CNT-coated MF foam approaches the chloroform layer at the bottom of water. These phenomena explain the selective sorption capacity of the CNTs-coated MF foam. In addition to the separation ability of oil from water, recyclability is also an important factor to evaluate the performance of the sorbent. As the created MF foam is a rigid foam, the recoverability of absorbed oils or solvents is carried out only through distillation and the recycling of the sorbent can be carried out via distillation or combustion process (Fig. 6d). The results show that no significant change in oil sorption capacity of CNTs-coated MF foam was found after 5 cycles of sorption-combustion.
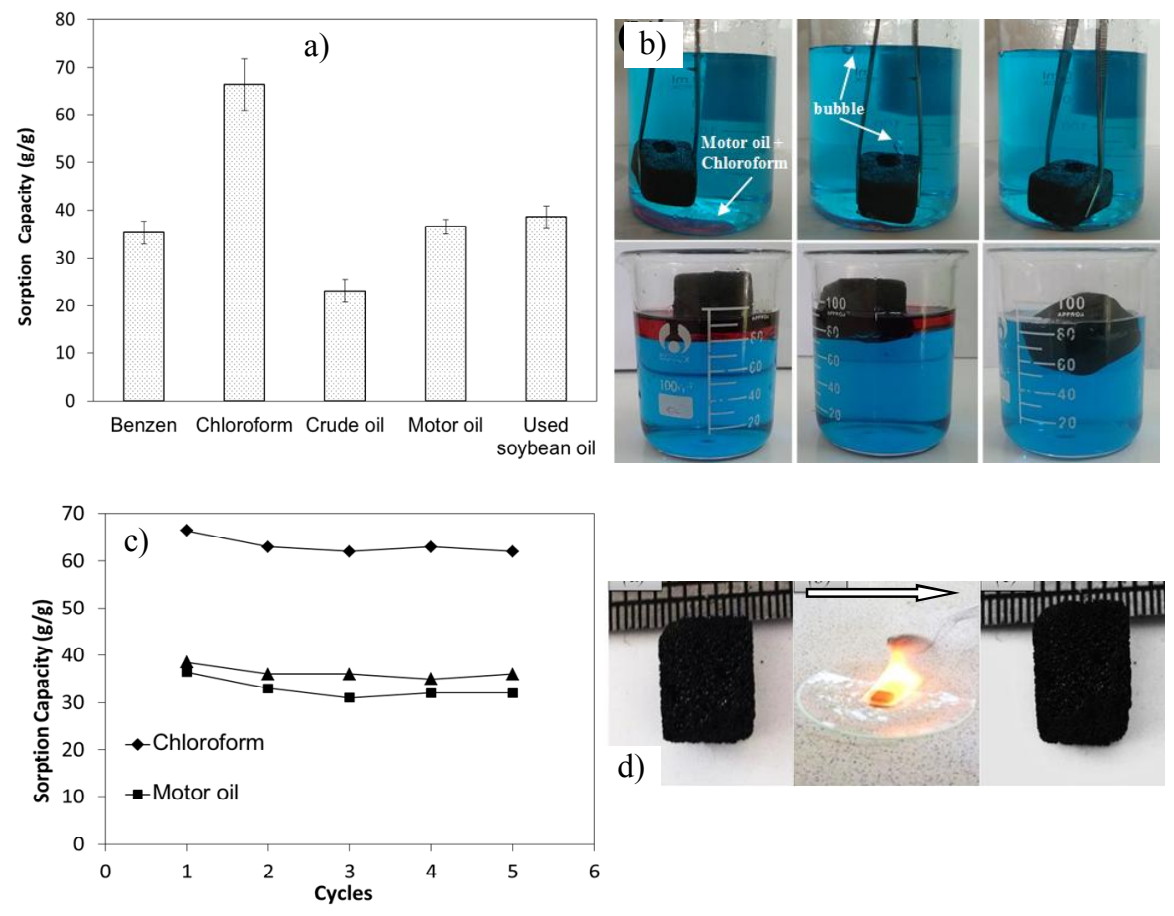

Fig. 6. Oil sorption capacities of CNTs-coated MF foam (a); removal of chloroform layer (dyed with motor oil) sank to the bottom of water and motor oil layer on water surface (b); oil sorption capacities of CNTs-coated MF foam after 5 cycles of sorption-combustion (c) and recyclability of CNTs-coated MF (d)

\section{Conclusions}

A green, simple and cost-effective method was used to produce the hydrophobic CNTs-coated MF foam applied for cleaning up oil spills. The MF foam produced had the structure and apparent density that are favorable for a sorbent material. Decoration of CNTs on the MF foam did not show any effect on its pristine porous structure but changed its characteristic hydrophilic form to hydrophobic one and shifted the decomposition temperature to a higher value. The prepared CNTs-coated
MF foam presented a broad sorption of oils and common organic solvents with high sorption capacity up to 66 times its own weight, high selectivity and good recyclability. We believe that the CNTs-coated MF foam produced by using the proposed method is a promising candidate for the removal of oil from water.

\section{Acknowledgements}

This research is funded by Funds for Science and Technology Development of the University of Danang under project number B2017-ĐN02-24. 


\section{References}

[1] Kujawinski E., Kido Soule M., Valentine D. et al.: Environ. Sci. Technol., 2011, 45, 1298. https://doi.org/10.1021/es103838p [2] Broje V., Keller A.: Environ. Sci. Technol., 2006, 40, 7914. https://doi.org/10.1021/es061842m

[3] Zahed M., Aziz H., Isa M. et al.: Bioresour. Technol., 2010, 101, 9455. https://doi.org/10.1016/j.biortech.2010.07.077

[4] Adebajo M., Frost R., Kloprogge J. et al.: J. Porous Mater., 2003, 10, 159. https://doi.org/10.1023/A:1027484117065

[5] Khin M., Nair A., Babu V. et al.: Energ. Environ. Sci., 2012, 5, 8075. https://doi.org/10.1039/C2EE21818F

[6] Singh V., Kendall R., Hake K., Ramkumar S.: Ind. Eng. Chem. Res., 2013, 52, 6277. https://doi.org/10.1021/ie4005942

[7] Angelova D., Uzunov I., Uzunova S. et al.: Chem. Eng. J., 2011, 172, 306. https://doi.org/10.1016/j.cej.2011.05.114

[8] Duong H., Burford R.: J. Appl. Polym. Sci., 2006, 99, 360. https://doi.org/10.1002/app.22426

[9] Ratcha A., Samart C., Yoosuk B. et al.: J. Appl. Polym. Sci., 2015, 132, 42688. https://doi.org/10.1002/app.42688

[10] Hu Y., Liu X., Zou J. et al.: ACS Appl. Mater. Inter., 2013, 5, 7737. https://doi.org/10.1021/am303294m

[11] Geim A., Novoselov K.: Nat. Mater., 2007, 6, 183. https://doi.org/10.1038/nmat 1849

[12] Sun Y., Wu Q., Shi G.: Energ. Environ. Sci., 2011, 4, 1113. https://doi.org/10.1039/C0EE00683A

[13] Gui X., Wei J., Wang K. et al.: Adv. Mater. Deerfield Beach Fla., 2010, 22, 617. https://doi.org/10.1002/adma.200902986 [14] Bi H., Xie X., Yin K. et al.: Adv. Funct. Mater., 2012, 22, 4421. https://doi.org/10.1002/adfm.201200888

[15] Yang Y., Tong Z., Ngai T., Wang C.: ACS Appl. Mater. Interface., 2014, 6, 6351. https://doi.org/10.1021/am5016342 [16] Luo Y., Jiang S., Xiao Q. et al.: Sci. Rep., 2017, 7, 7162. https://doi.org/10.1038/s41598-017-07583-0

[17] Zhu H., Chen D., Li N. et al.: Adv. Funct. Mater., 2015, 25, 597. https://doi.org/10.1002/adfm.201403864

[18] Dai Z., Weng C., Liu L. et al.: Sci. Rep., 2016, 6. https://doi.org/10.1038/srep32989

[19] Liu T., Zhao G., Zhang W. et al.: J. Porous Mater., 2015, 22, 1573. https://doi.org/10.1007/s10934-015-0040-8

[20] Merline D., Vukusic S., Abdala A.: Polym. J., 2013, 45, 413. https://doi.org/10.1038/pj.2012.162

[21] Ullah S., Bustam M., Nadeem M. et al.: Sci. World J., 2014, 2014. https://doi.org/10.1155/2014/940502
[22] Mijatovic J., Binder W., Kubel F., Kantner W.: Macromol. Symp., 2002, 181, 373. https://doi.org/10.1002/15213900(200205)181:1<373::AID-MASY373>3.0.CO;2-J

[23] Kandelbauer A., Wuzella G., Mahendran A. et al.: Chem. Eng. J., 2009, 152, 556. https://doi.org/10.1016/j.cej.2009.05.027 [24] Wang D., Zhang X., Luo S., Li S.: Adv. Mater. Phys. Chem., 2012, 2, 63. https://doi.org/10.4236/ampc.2012.24B018

[25] Manley T., Higgs D.: J. Polym. Sci. Polym. Symp., 1973, 42, 1377. https://doi.org/10.1002/polc.5070420337

[26] Devallencourt C., Saiter J., Fafet A., Ubrich E.: Thermochim. Acta, 1995, 259, 143. https://doi.org/10.1016/0040-6031(95)02262-Z [27] Edwards E., Antunes E., Botelho E. et al.: Appl. Surf. Sci., 2011, 258, 641. https://doi.org/10.1016/j.apsusc.2011.07.032 [28] Abdala A., Merline D., Vukusic S.: Polym. J., 2012, 45, 413. https://doi.org/10.1038/pj.2012.162

[29] Nemanič V., Zajec B., Žumer M. et al.: Appl. Energ., 2014, 114, 320. https://doi.org/10.1016/j.apenergy.2013.09.071

[30] Wang C.-F., Lin S.-J.: ACS Appl. Mater. Inter., 2013, 5, 8861. https://doi.org/10.1021/am403266v

[31] Gui X., Zeng Z., Lin Z. et al.: ACS Appl. Mater. Inter., 2013, 5, 5845. https://doi.org/10.1021/am4015007

Received: April 19, 2019 / Revised: May 10, 2019 / Accepted: October 29, 2019

\section{СИНТЕЗ ТА ПРИГОТУВАННЯ ЕКОЛОГІЧНИМ І ПРОСТИМ МЕТОДОМ ГЦДРОФОБНОЇ МЕЛАМІНО-ФОРМАЛЬДЕГЦДНОЇ ПІНИ, ПОКРИТОЇ ВНТ ДЛЯ ЕФЕКТИВНОГО РОЗДІЛЕННЯ НАФТА/ВОДА}

Анотація. Представлено екологічний, простий $i$ економічно ефективний метод заміни гідрофільної меламіноформальдегідної (МФ) піни на МФ-піну з покриттям гідрофобними вуглечевими нанотрубками (ВНТ) за допомогою процесу занурення. МФ-піну одержано з МФ-смоли, синтезованої в лабораторії реакиією конденсаиії між меламіном та формальдегідом за лужних умов з мольним співвідношенням меламіну до формальдегіду 1:3. Встановлено, що МФ-піна має структуру з відкритими порами із середнім діаметром 350 мкм, щүільністю $25 \kappa 2 \cdot \mathrm{M}^{-3}$ та пористістю $98 \%$. Визначено, щчо МФ-піна з покриттям ВНТ має високу сорбиійну здатність (23-66 г/2) для нафт та органічних розчинників, можливість утилізації та високу селективність.

Ключові слова: вуглецева нанотрубка, меламінова піна, меламіноформальдегід, розливи нафти, сорбентний матеріал. 